\title{
MENINGKATKAN KEMAMPUAN GURU DALAM MENYUSUN INSTRUMEN PENILAIAN BENTUK TES TERTULIS MELALUI BIMBINGAN BERBASIS LEMBAR KERJA DI SMP NEGERI 7 BANJARMASIN
}

\author{
Abdul Hamid ${ }^{1}$ \\ 1. SMP Negeri 7 Banjarmasin \\ ahamid_66@yahoo.co.id (085251130866)
}

\begin{abstract}
ABSTRAK
Meningkatkan Kemampuan Guru dalam Menyusun Instrumen Penilaian Bentuk Tes Tertulis Melalui Bimbingan Berbasis Lembar Kerja (LK) di SMP Negeri 7 Banjarmasin. Penelitian tindakan sekolah ini bertujuan untuk mendapatkan informasi tentang penerapan model Bimbingan Berbasis Lembar Kerja dalam meningkatkan kemampuan guru menyusun instrumen penilaian bentuk tes tertulis di SMP Negeri 7 Banjarmasin. Penelitian ini dilaksanakan di SMP Negeri 7 Banjarmasin dengan subjek penelitian sebanyak 24 orang guru. Penelitian ini dilaksanakan dengan 2 siklus dengan tahapan kegiatan mulai perencanaan, pelaksanaan, pengamatan/observasi dan refleksi. Data berupa kompetensi yang dicapai guru dalam menyusun tes bentuk tertulis diperoleh dengan melakukan penskoran terhadap hasil kerja guru dalam bentuk lembar kerja (LK). Hasil penelitian menunjukkan bahwa penerapan model Bimbingan Berbasis Lembar Kerja (LK) dapat meningkatkan kemampuan guru dalam menyusun instrumen penilaian bentuk tes tertulis di SMP Negeri 7 Banjarmasin.
\end{abstract}

Kata Kunci: instrument penilaian bentuk tertulis, lembar kerja

\section{PENDAHULUAN}

Guru sebagai tenaga profesional memiliki kewajiban merencanakan pembelajaran, melaksanakan proses pembelajaran yang bermutu dan menilai atau mengevaluasi hasil pembelajaran (Undang-Undang RI Nomor 14 Tahun 2005). Komponen-komponen tersebut mempunyai hubungan yang erat satu sama lainya. Pembelajaran di kelas tidak akan terlaksana secara baik tanpa perencanaan yang baik. Perencanaan pembelajaran yang telah disusun tersebut menjadi dasar atau arah pelaksanaan proses pembelajaran. Rencana pembelajaran dan pelaksanaan pembelajaran juga menjadi dasar penyusunan dan pelaksanaan penilaian. Sebaliknya, selain berfungsi untuk mengetahui sejauhmana siswa telah pencapaian kompetensi yang telah ditentukan, penilaian juga digunakan sebagai umpat balik apakah perencanaan dan pelaksanaan pembelajaran tersebut memberikan hasil yang baik atau sebaliknya (Djiwandono, 1996:5).

Menurut Furqon (1999:10), penilaian seyogyanya tidak hanya digunakan untuk menentukan status belajar siswa, melainkan harus dipahami dan dilakukan sebagai strategi untuk menentukan mutu dan keberhasilan kegiatan belajar mengajar. Karena itu penilaian harus diarahkan untuk memenuhi tiga fungsi utamanya yaitu: (a) mendorong siswa untuk meningkatkan kegiatan belajar; (b) memberi informasi kepada guru untuk meningkatkan kemampuan dan keefektifan mengajar; dan (c) memberi informasi kepada siswa untuk meningkatkan keefektifan belajar. 
Berdasarkan uraian di atas dapat kita simpulkan bahwa penilaian punya peran yang sangat penting dalam pembelajaran. Untuk itu sebelum dilaksanakan, penilaian perlu direncanakan dan disusun secara benar. Menurut Permendiknas No. 20 Tahun 2007, salah satu prinsip penilaian adalah menyeluruh dan berkesinambungan. Ini berarti bahwa penilaian oleh pendidik harus mencakup semua aspek kompetensi dengan menggunakan berbagai teknik penilaian yang sesuai untuk memantau perkembangan kemampuan peserta didik. Tes adalah salah satu alat yang digunakan dalam kegiatan penilaian

Selama ini penilaian oleh pendidik di SMP Negeri 7 Banjarmasin yaitu pada ulangan harian dan ulangan tengah semester hanya menggunakan satu macam alat penilaian yaitu bentuk uraian dan sebagian kecil menggunakan bentuk pilihan ganda pada ulangan tengah semester. Alat ukur atau tes yang digunakan tersebut kebanyakan menggunakan soal yang sudah ada di dalam buku pelajaran atau buku kumpulan soal-soal. Kemudian soal-soal yang digunakan juga belum pernah dilakukan telaah minimal secara kualitatif. Sehingga kualitas alat ukur yang digunakan tidak dapat diketahui secara jelas. Hal ini mengindikasikan ada yang masih kurang dalam pelaksanaan penilaian.

Kemudian berdasarkan hasil pengamatan di lapangan pada saat ulangan harian atau UTS guru belum sepenuhnya menguji semua kompetensi yang sudah diajarkan. Berdasarkan analisis hasil evaluasi Rencana Pelaksanaan Pembelajaran (RPP) semester 1 tahun pelajaran 2015-2016 sebagai salah satu bagian dari kegiatan supervisi akademik diketahui bahwa hanya $61,10 \%$ guru yang mampu menentukan teknik dan bentuk penilaian dan hanya 55,60\% guru yang mampu membuat instrumen penilaian. Hal di atas mengambarkan adanya masalah yang dihadapi guru dalam hal penilaian hasil belajar khususnya dalam penyusunan alat penilaian atau tes.

Berdasarkan latar belakang di atas perlu upaya untuk meningkatkan kemampuan guru dalam menyusun alat penilaian. Bimbingan berbasis Lembar Kerja adalah suatu model bimbingan yang mana guru menggali sendiri informasi berdasarkan tugas atau petunjuk yang diberikan melalui Lembar Kerja. Hal ini sesuai dengan prinsip pembelajaran orang dewasa.

Guru sebagai orang dewasa lebih tertarik belajar melalui kegiatan mengalami sesuatu. Jadi tidak akan banyak hasilnya jika mereka diceramahi dan digurui untuk melakukan sesuatu. Kegiatan belajar dengan cara langsung melakukan merupakan salah satu pendorong mereka untuk bisa belajar aktif. Untuk itu kegiatan pembelajaran orang dewasa seyogyanya banyak melibatkan mereka dalam proses pembelajaran. Agar keterlibatan peserta dalam pembelajaran dominan maka lebih baik pembelajarannya berbasis masalah. Hal tersebut sesuai dengan beberapa prinsip utama pembelajaran orang dewasa yaitu "Adults learn by doing. Active participation is especially important to adult learners. Adult learning is problem-based and these problems must be realistic. Adult learners like finding solutions to problems." (https://en.wikipedia.org/wiki/ Adult_education).

Selain itu, harus diakui juga bahwa setiap pribadi memiliki keunikan dan orang dewasa bukan kumpulan orang pasif yang hanya menerima gagasan seseorang, nilai-nilai, dan jawaban orang lain. Mereka adalah mahluk yang aktif dan kreatif yang memerlukan kesempatan untuk mendiskusikan masalah-masalah yang dihadapinya. Mereka juga lebih senang kalau bisa turut berpikir dan 
mengemukakan pendapatnya, daripada fasilitator atau narasumber menjejalkan teori dan gagasannya sendiri kepada mereka (Hotibin. http://kangebink.blogspot.co.id/2013/08/andragogi-pendidikan-orangdewasa.html).

Berdasarkan uraian di atas dapat disimpulkan bahwa dalam pembelajaran orang dewasa diperlukan teknik pembelajaran yang tidak menggurui dan berbasis masalah sehingga dapat melibatkan langsung secara aktif peserta pembelajar dalam proses pembelajaran. Bimbingan berbasis lembar kerja adalah salah satu alternatif yang dapat dilaksanakan dan diharapkan dapat menjadi solusi terhadap permasalahan guru sebagaimana dikemukakan pada bagian terdahulu.

Pada umumnya Lembar Kerja dalam kaitannya dengan kegiatan pembelajaran mengacu pada lembar kertas yang berisi pertanyaan dan tempat untuk merekam jawaban (https://en.wikipedia.org/ wiki/Worksheet). Lembar kerja seperti ini berfungsi sebagai penuntun belajar. Lembar kerja ini ini berisi pertanyaan atau isian yang jawabannya ada di dalam buku. Pembelajar akan dapat mengerjakan LK tersebut jika ia membaca buku, sehingga fungsi utama LK ini adalah membantu pembelajar memahami materi pembelajaran yang terdapat di dalam buku (Depdiknas, 2008).

Penelitian tindakan sekolah ini bertujuan untuk mendapatkan informasi tentang penerapan model Bimbingan Berbasis Lembar Kerja (LK) dalam meningkatkan kemampuan guru menyusun tes bentuk tertulis di SMP Negeri 7 Banjarmasin

\section{METODE}

Jumlah guru yang menjadi subjek penelitian ini ada 24 orang. Penelitian tindakan sekolah ini dilaksanakan di SMP Negeri 7 Banjarmasin yang beralamat di Jalan Veteran Km. 4,5 Banjarmasin. Penelitian ini dilaksanakan sebanyak 2 siklus dengan tahapan kegiatan mulai perencanaan, pelaksanan, pengamatan/observasi dan refleksi serta revisi perencanaan

\section{A. Perencanaan}

Pada tahap perencanaan peneliti melakukan beberapa kegiatan: pertama, setelah memperhatikan dan mencermati hasil analisis telaah perencanaan pembelajaran (RPP) diketahui bahwa tingkat capaian kemampuan guru pada komponen menentukan teknik dan bentuk penilian berada pada posisi terendah ketiga $(61,10 \%)$ dan komponen penyusunan instrumen penilaian menduduki peringkat terendah pertama $(55,60 \%)$, peneliti kemudian menindaklanjutinya dengan merumuskan permasalahan secara operasional dan upaya pemecahannya. Selain itu, peneliti juga membuat lembar kerja (LK) dan bahan bacaan yang akan digunakan, membuat instrumen untuk mengukur hasil yang dicapai, membuat lembar observasi dan angket untuk melihat aktivitas dan tanggapan guru-guru terhadap tindakan yang dilaksanakan peneliti. Peneliti juga menyiapkan pembagian kelompok supaya setiap kelompok memiliki kemampuan yang seimbang dan mewakili setiap mata pelajaran. Terakhir peneliti mengadakan pengarahan/diskusi dengan teman sejawat yang akan membantu melakukan pengamatan mengenai hal-hal yang perlu diamati. 


\section{B. Pelaksanaan}

Berdasarkan hasil musyawarah dengan wakil kepala sekolah dan memperhatikan masukan dari beberapa orang guru, maka kegiatan penelitian ini diputuskan mulai dilaksanakan pada akhir bulan Maret sampai dengan bulan Mei 2016. Kegiatannya dilaksanakan sejak pagi hari hingga siang hari. Semua guru yang pada hari tersebut ada tugas mengajar di kelas diwajibkan memberikan tugas. Kegiatan penilitian ini dilaksanakan sebanyak dua siklus. Setiap siklus dilaksanakan dalam 2 kali pertemuan. Pada siklus pertama dibahas tentang pengertian penilaian, pengukuran dan tes, tes bentuk uraian dan tes bentuk jawaban singkat. Pada siklus kedua membahas bentuk tes Benar-Salah, tes bentuk menjodohkan dan bentuk pilihan ganda.

\section{Pengamatan/Observasi}

Kegiatan pengamatan/observasi dilaksanakan secara simultan dengan pelaksanaan bimbingan. Peneliti adalah pelaku tindakan sekaligus sebagai pengamat. Peneliti juga minta bantuan guru BK dalam melakukan pengamatan untuk melihat semangat kerja guru dalam mengerjakan tugas.

\section{Refleksi}

Pada tahapan ini peneliti melakukan kegiatan menganalisis, mensintesis, menginterpretasi dan memberikan eksplanasi terhadap semua informasi yang diperoleh baik dari hasil pengamatan maupun hasil penilaian terhadap LK yang telah dikerjakan masing-masing guru.

Berdasarkan hasil refleksi dapat ditarik kesimpulan apakah tindakan yang dilakukan telah sesuai dengan harapan atau belum, apa yang yang harus dipertahankan dan apa yang harus direvisi kembali. Selanjutnya dilakukan penyusunan perencanaan tindakan yang baru berdasarkan hasil refleksi untuk siklus berikutnya.

\section{E. Jenis Instrumen dan Cara Penggunaannya}

Hasil kerja guru dalam menyelesaikan tugas dalam bentuk LK tidak hanya menggambarkan pengetahuan tetapi sekaligus menggambarkan kemampuan mereka dalam menyusun tes bentuk tertulis. Untuk keperluan tersebut diperlukan alat ukur berupa pedoman penskoran atau kunci jawaban. Untuk melengkapi informasi terkait penerapan model bimbingan tersebut perlu untuk melihat semangat kerja guru dalam mengerjakan LK. Hal-hal yang terkait dengan semangat kerja guru tersebut direkam melalui lembar observasi oleh observer yang dalam hal ini dilaksanakan oleh peneliti sendiri dan dibantu guru BK.

Untuk mendapatkan informasi tambahan mengenai kegiatan pelaksanaan bimbingan, peneliti merasa perlu juga meminta pendapat langsung dari guru yang bersangkutan. Melalui angket diharapkan dapat diketahui tanggapan guru-guru terhadap tindakan bimbingan yang dilakukan apakah sesuai dengan mereka dan memberikan manfaat dalam meningkatkan pengetahuan dan kemampuan dalam menyusun tes bentuk tertulis. 


\section{F. Pelaksanaan Tindakan}

\section{Tindakan Bimbingan pada Siklus I}

Tindakan bimbingan pada siklus I dilaksanakan sebanyak 2 pertemuan yaitu pada minggu terakhir bulan Maret dan awal bulan April 2016 (Rabu, 30 Maret 2016 dan Jumat, 1 April 2016). Pada hari Rabu kegiatan dimulai pukul 8.30 sampai 14.15. Pada hari Jumat dimulai pulul 7.30 s.d. 11.00. Langkah awal yang dilakukan adalah mempersilakan subjek penelitian (guru) memasuki tempat kegiatan yaitu di ruang aula sekolah dan menempati tempat duduk yang sudah ditentukan. Setelah semua peserta berada pada kondisi siap untuk mengikuti kegiatan bimbingan, peneliti membuka kegiatan dengan mengucapkan salam dan tegur sapa. Kegiatan dilanjutkan dengan mengingatkan kembali pentingnya penilaian dalam pembelajaran. Hal ini dilakukan melalui diskusi terbimbing dengan mencermati bagan tentang hubungan tiga komponen penting dalam proses pembelajaran yang ditayangkan melalui slide. Di akhir diskusi peneliti memberikan penegasan tentang pentingnya penilaian, pengukuran dan tes.

Langkah selanjutnya adalah membagikan bahan bacaan dan lembar kerja serta petunjuk kegiatan pembimbingan dan target yang ingin dicapai. Peneliti meminta salah seorang peserta untuk membacakan petunjuk kegiatan dan target yang ingin dicapai. Peserta dari kelompok yang lain juga diminta untuk membaca petunjuk kegiatan dan target yang ingin dicapai. Hal ini dimaksudkan agar semua peserta paham apa yang akan dilakukan dan apa yang harus dicapai oleh setiap peserta.

Sebelum melanjutkan ke tahap berikutnya, peneliti mengajak semua peserta untuk mengucapkan dengan nyaring slogan "AKU ADALAH GURU YANG HEBAT KARENA AKU MAU BELAJAR". Kalimat ini diulang secara serentak beberapa kali dengan suara nyaring. Peneliti kemudian meminta peserta mengerjakan LK-1. Peneliti membatasi waktu. Setelah batas watu yang ditentukan berakhir, setiap peserta diminta menyampaikan hasil kerjanya. Peneliti meminta kelompok lain menanggapi. Selesai pembahasan LK-1 dilanjutkan dengan mengerjakan LK-2. Peneliti kembali membatasi waktu. Salah satu kelompok yang lain disuruh melaporkan hasil pekerjaannya. Sama halnya dengan kegiatan yang pertama, kelompok yang lain diminta menanggapi hasil kerja kelompok penyaji. Di setiap kurun waktu peserta mengerjakan LK, peneliti selalu berkeliling mengamati perilaku peserta. Siklus kegiatan seperti ini selalu dilakukan pada setiap mengerjakan LK.

Selesai mendiskusikan hasil kerja LK-6 dan mengingat waktu yang tersisa sangat terbatas, maka kegiatan peserta langsung mengerjakan LK-9. Setelah selesai pembahasan LK-9 dilanjutkan ke LK-10. Alasan kenapa kedua LK tersebut didahulukan karena kedua LK tersebut membahas tentang teori. Selesai pembahasan LK tersebut dan waktu sudah menunjukkan puluk 14.15 maka kegiatan pembimbingan pada hari pertama dinyatakan berakhir.

Pertemuan lanjutan dilaksanakan pada hari Jumat, 1 April 2016. Kegiatan dimu-lai pada pukul 8.00 sampai pukul 11.00 siang. Semua kelompok masih mengerjakan tu-gas LK-7. Waktu pengerjaan kembali dibatasi. Setelah sampai batas waktu yang ditentukan, salah satu kelompok diminta mempresentasikan hasil kerjanya dan kelompok lain menanggapi. Setelah melalui diskusi yang hangat, akhirnya LK-7 bisa diselesaikan. Kegiatan dilanjutkan dengan laporan hasil kerja LK-8. Ini adalah tugas kelompok lain untuk mempresentasikan hasil 
kerja mereka. Kelompok lainnya bertindak sebagai penanggap. Kegiatan yang serupa dilanjutkan untuk pembahasan LK-11. Semua LK dapat dibahas secara bersama-sama. Seiring dengan selesainya pembahasan LK-11 waktu yang tersedia juga habis. Peneliti akhirnya menutup kegiatan siklus I pertemuan 2.

\section{Tindakan Bimbingan pada Siklus II.}

Pelaksanaan tindakan siklus II merupakan penyempurnaan dari tindakan pada siklus I. Kegiataan ini dilaksanakan pada hari Senin, 18 April 2016. Kegiatan bimbingan yang dilaksanakan pada siklus II tidak terlalu berbeda dari siklus I. Langkah awal yang dilakukan adalah mempersilahkan subyek penelitian (guru) memasuki tempat kegiatan yaitu di ruang aula sekolah dan menempati tempat duduk yang sudah ditentukan. Setelah semua peserta berada pada kondisi siap untuk mengikuti kegiatan bimbingan, peneliti membuka kegiatan dengan mengucapkan salam dan tegur sapa. Kegiatan dilanjutkan dengan penyampaian hasil capaian peserta bimbingan pada kegiatan bimbingan siklus I berupa skor dan aktivitas peserta selama kegiatan bimbingan. Selain itu juga disampaikan hal-hal yang belum terlaksana secara optimal yang punya pengaruh terhadap pencapaian kompetensi

Langkah selanjutnya adalah membagikan lembar kerja dan petunjuk kegiatan pembimbingan serta target yang ingin dicapai pada Siklus II. Peneliti meminta salah seorang peserta untuk membacakan petunjuk kegiatan dan target yang ingin dicapai. Peserta dari kelompok yang lain juga diminta kembali untuk membaca petunjuk pelaksanaan kegiatan dan target yang ingin dicapai. Hal ini dimaksudkan agar semua peserta paham apa yang akan dilakukan dan apa yang harus dicapai oleh setiap peserta. Hal yang berbeda pada petunjuk pelaksanaan kegiatan pembelajaran ini dari yang sebelumnya adalah adanya penunjukkan ketua kelompok dan koreksi dilaksanakan secara silang

Seperti halnya pada siklus I setiap peserta diminta mengucapkan slogan "AKU ADALAH GURU YANG HEBAT KARENA AKU MAU BELAJAR". Kalimat ini diulang secara serentak beberapa kali dengan suara nyaring. Peneliti melanjutkan kegiatan dengan meminta peserta mengerjakan LK-12. Peneliti membatasi waktu. Setelah batas watu yang ditentukan berakhir, setiap kelompok mengumpulkan lembar kerja anggota kelompoknya, kemudian diserahkan ke kelompok lain untuk dilakukan koreksi silang. Salah satu kelompok diminta menyampaikan hasil kerjanya dan kelompok lain menanggapi. Setelah ditemukan jawaban yang benar, baru masing-masing kelompok melakukan koreksi terhadap hasil kerja kelompok lain.

Selesai pembahasan LK-12 dilanjutkan dengan mengerjakan LK-13. Peneliti kembali melakukan hal yang sama seperti pada saat mengerjakan LK-12. Setelah selesai membahas LK-13, kegiatan yang sama kembali dilakukan untuk LK-14, LK-15, LK-16 dan LK-17. Semua LK yang dikerjakan tersebut semuanya membahas tentang teori. Selesai pembahasan LK tersebut dan waktu sudah menunjukkan puluk 14.20 maka kegiatan pembimbingan pada hari pertama siklus ke dua dinyatakan berakhir.

Pertemuan lanjutan dilaksanakan pada hari Sabtu, 21 Mei 2016. Kegiatan dimu-lai pada pukul 8.15 sampai pukul 12.15 siang. Semua kelompok masih mengerjakan tu-gas LK-18 sampai dengan LK-20. Waktu pengerjaan kembali dibatasi. Setelah sampai batas waktu yang ditentukan, salah satu kelompok diminta mempresentasikan hasil kerjanya dan kelompok lain menanggapi. Setelah 
melalui diskusi yang hangat akhirnya pembahan LK-18 bisa diselesaikan. Kegiatan dilanjutkan dengan laporan hasil kerja LK-19. Ini adalah tugas kelompok lain untuk presentasikan hasil kerja mereka. Kelompok lainnya bertindak sebagai penanggap. Kegiatan yang serupa dilanjutkan untuk pembahasan LK-20. Akhir nya semua LK dapat dibahas secara bersama-sama. Seiring berakhirnya waktu peneliti akhirnya menutup kegiatan siklus II pertemuan ke 2

\section{G. Cara Pengamatan}

Kegiatan pengamatan dilakukan untuk melihat aktivitas guru selama kegiatan pembimbingan. Hal ini dimaksudkan untuk melihat semangat kerja mereka dalam mengikuti kegiatan, khususnya dalam menyusun instrumen penilaian bentuk tes tertulis. Dalam kegiatan ini selain sebagai pembimbing, peneliti juga berperan sebagai pengamat (observer). Agar semua peserta dapat teramati setiap saat, peneliti juga melibatkan pihak lain (guru BK) untuk membantu melakukan pengamatan terhadap setiap peserta bimbingan. Pengamatan dilakukan dengan menggunakan lembar pengamatan. Pengamatan dimulai sejak guru memasuki ruang bimbingan. Melalui pengamatan dapat dilihat kehadiran, tanggungjawab, kerja keras, kerja sama dan sikap/perasaan peserta selama melaksanakan tugas (LK).

\section{H. Analisis Data dan Refleksi}

Data yang dikumpulkan melalui penelitian ini berupa data kuantitatif dan kualitatif. Data kuantitatif adalah data hasil penskoran terhadap hasil kerja peserta bimbingan dalam bentuk lembar kerja (LK). Untuk memperoleh informasi yang bermanfaat dari hasil penskoran, maka perlu dilakukan analisis per butir tugas untuk melihat capaian secara keseluruhan. Hasil analisis kemudian dilakukan katagorisasi dengan mengunakan kriteria sebagai berikut:

$$
\begin{aligned}
86-100 & =\text { Baik Sekali } \\
70-85 & =\text { Baik } \\
55-69 & =\text { Cukup } \\
<55 & =\text { Kurang }
\end{aligned}
$$

Sedangkan data kualitatif yang diperoleh dari hasil observasi dan angket dilakukan pengklasifikasian dan kemudian dilihat kecenderungan umumnya. Hasil analisis data baik yang berupa data kuantitatif maupun data kualitatif dijadikan dasar untuk melakukan refleksi untuk melihat dampak dari tindakan yang dilakukan, kelemahan dan kelebihan yang ditemukan. Berdasarkan hasil refleksi tersebut dapat disusun rencana tindakan yang dilaksanakan pada siklus berikutnya.

\section{HASIL DAN PEMBAHASAN}

\section{Hasil}

\section{A. Hasil Bimbingan Siklus I}

Sesuai skenario yang disusun, telah dilaksanakan kegiatan pembimbingan penyusunan tes bentuk tertulis. Sebagaimana telah dikemukakan sebelumnya bahwa dari hasil kerja peserta bimbingan melalui LK dapat diketahui capaian berupa pengetahuan tentang tes bentuk tertulis dan juga kemampuan menyusun 
soalnya. Berdasarkan rekapitulasi hasil kerja tersebut dapat ditampilkan data sebagai berikut .

Tabel 1. Skor Perolehan Hasil kerja Peserta Melalui LK pada Siklus I

\begin{tabular}{|c|c|c|c|c|c|}
\hline $\begin{array}{l}\text { ASPEK } \\
\text { TUGAS }\end{array}$ & LK & $\begin{array}{l}\text { NOMOR } \\
\text { BUTIR } \\
\text { LK }\end{array}$ & $\begin{array}{c}\text { PERSENTASE } \\
\text { KETERCAPAIAN }\end{array}$ & $\begin{array}{l}\text { RATA- } \\
\text { RATA }\end{array}$ & KATAGORI \\
\hline \multirow{15}{*}{ 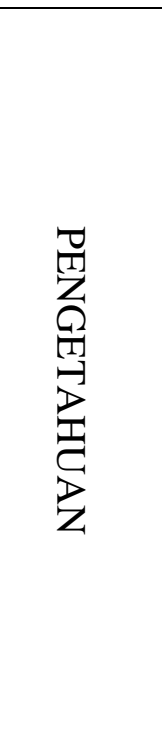 } & \multirow{2}{*}{ LK-1 } & 1 & $82,80 \%$ & \multirow{15}{*}{$84,63 \%$} & \multirow{15}{*}{ BAIK } \\
\hline & & 2 & $63,90 \%$ & & \\
\hline & LK-2 & 1 & $92,60 \%$ & & \\
\hline & \multirow{2}{*}{ LK-3 } & 1 & $95,40 \%$ & & \\
\hline & & 2 & $97,50 \%$ & & \\
\hline & \multirow{3}{*}{ LK-4 } & 1 & $84,40 \%$ & & \\
\hline & & 2 & $95,00 \%$ & & \\
\hline & & 3 & $100 \%$ & & \\
\hline & LK-5 & 1 & $95,20 \%$ & & \\
\hline & LK-6 & 1 & $57,50 \%$ & & \\
\hline & \multirow{3}{*}{ LK-9 } & 1 & $95,50 \%$ & & \\
\hline & & 2 & $63,60 \%$ & & \\
\hline & & 3 & $95,80 \%$ & & \\
\hline & \multirow{2}{*}{ LK-10 } & 1 & $74,30 \%$ & & \\
\hline & & 2 & $76,00 \%$ & & \\
\hline \multirow{3}{*}{ 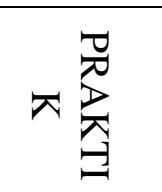 } & LK-7 & 1 & $81,80 \%$ & \multirow{3}{*}{70,42} & \multirow{3}{*}{ Baik } \\
\hline & LK-8 & 1 & $70,80 \%$ & & \\
\hline & LK-11 & 1 & $58,60 \%$ & & \\
\hline
\end{tabular}

Data di atas menunjukkan bahwa secara umum capaian penguasaan terkait pengetahuan tentang soal bentuk tertulis khususnya bentuk uraian dan bentuk jawaban singkat termasuk katagori Baik $(84,63 \%)$. Dari 15 butir soal/tugas yang diberikan melalui LK sebanyak 8 butir yang termasuk katagori Baik Sekali. Delapan butir tersebut adalah LK-2 terkait prinsip penilaian (92,60\%), LK-3 butir 1 tentang teknik penilaian dari tes tertulis $(95,40 \%)$, butir 2 nya tentang bentuk penilaian tes tertulis $(97,50 \%)$, LK-4 butir 2 tentang jenis tes bentuk uraian $(95,00 \%)$, butir 3 nya tentang kapan sebaiknya menggunakan tes bentuk uraian bebas (100\%), LK-5 tentang kaidah penulisan soal uraian $(95,20 \%)$, LK-9 butir 1 terkait pengertian soal jawaban singkat $(95.50 \%)$, butir 3 tentang kapan sebaiknya mengunakan Soal Jawaban Singkat $(95,80 \%)$. Sebanyak 4 butir soal/tugas yang termasuk katagori Baik yaitu: LK-1 butir 1 tentang pengertian penilaian dan pengukuran (82,80\%), LK-4 butir 1 tentang pengertian tes uraian $(84,40 \%)$, dan LK-10 butir 1 tentang keunggulan dan kelemahan bentuk soal jawaban pendek $(74,30 \%)$ dan butir 2 tentang kaidah penyusunan soal bentuk jawaban singkat (76,00\%). Butir soal/tugas yang memperoleh nilai katagori Cukup ada 3 buah yaitu: LK-1 butir 2 tentang perbedaan antara penilaian, pengukuran dan tes $(63,90 \%)$, LK-6 terkait kelebihan dan kekurangan soal bentuk uraian $(57,50 \%)$ dan LK-9 butir 2 terkait bentuk soal jawaban singkat $(63,60 \%)$.

Setelah mencermati setiap jawaban pada butir soal/tugas yang masih termasuk katagori Baik dan Kurang diketahui bahwa sebagian besar dari peserta 
bimbingan memberikan jawaban sudah benar namun tidak lengkap. Hanya sebagian kecil saja yang jawabannya salah. Kesalahan tersebut tampak disebabkan kurang cermat memahami pertanyaan atau tugas yang diberikan.

Di sisi lain diketahui bahwa skor yang diperoleh masing-masing peserta dari kelompok yang sama juga berbeda- beda. Hal ini menggambarkan bahwa mereka bekerja secara individu. Memang semua peserta sangat aktif mengikuti kegiatan, namun sayang mereka belum memanfaatkan kerja sama kelompok secara maksimal.

Dari aspek praktik, secara umum kemampuan peserta dalam menyusun soal bentuk tertulis khususnya bentuk uraian dan bentuk jawaban singkat termasuk katagori Cukup $(68,142 \%)$. Dilihat dari kemampuan menyusun soal bentuk uraian non objektif (LK-7) termasuk katagori Baik $(75,00 \%)$. Hasil capaian kemampuan penyusunan soal bentuk uraian objektif (LK-8) sebesar $70,80 \%$. Ini juga termasuk katagori Baik. Hasil capaian yang termasuk katagori Cukup adalah LK-11 yaitu terkait dengan kemampuan menyusun soal jawaban singkat $(58,60 \%)$. Dari 24 peserta yang membuat soal tersebut terdapat 7 orang $(29,16 \%)$ peserta yang salah jawabannya

Berdasarkan uraian di atas dapat dikemukakan bahwa kegiatan penyusunan tes bentuk tertulis melalui bimbingan berbasis Lembar Kerja (LK) pada siklus I sudah dapat menunjukkan capaian yang positif dalam hal pengetahuan dan kemampuan menyusun tes bentuk tertulis tersebut. Hal ini ditunjukkan dengan 18 orang dari 24 peserta dapat menyusun soal bentuk uraian non-objektif. Sebanyak 17 peserta dapat menyusun soal bentuk uraian objektif. Sedangkan untuk soal jawaban singkat hanya 7 peserta $(28 \%)$ yang salah dalam menyusun soal bentuk jawaban singkat. Yang sisanya hanya ada kesalahan kecil dan juga mereka hanya membuat satu soal padahal yang diminta 2 butir soal. Kurang teliti dalam membaca soal dan kurang cermat dalam membaca bahan bacaan serta kerjasama sesama anggota kelompok yang belum optimal menjadi salah satu penyebab belum maksimalnya capaian hasil pembimbingan. Belum optimalnya kerja sama anggota kelompok dapat terlihat dari skor masing-masing anggota dalam satu kelompok berbeda-beda. Karena itu pada kegiatan bimbingan siklus II dilakukan beberapa perubahan.

\section{B. Hasil Bimbingan Siklus II}

Sebagaimana telah dikemukakan di atas bahwa ada temuan yang dianggap berpengaruh terhadap belum optimalnya hasil yang diperoleh dari kegiatan bimbingan pada siklus I. Menindaklanjuti temuan tersebut, maka dalam kegiatan bimbingan pada siklus II diadakan perbaikan/penyempurnaan. Ada beberapa kegiatan tambahan yang dilakukan. Pada bagian awal kegiatan peneliti menyampaikan skor yang diperoleh masing-masing peserta dari setiap kelompok. Hal ini dimaksudkan untuk memotivasi peserta agar terdorong untuk memperoleh hasil yang maksimal pada kegiatan bimbingan di siklus II. Peneliti juga menyampaikan penyebab belum maksimalnya hasil yang dicapai seperti kurang teliti menbaca soal atau tugas, kurang lengkapnya jawaban, tidak teliti dan cermat dalam membaca bahan bacaan dan kerja sama anggota kelompok masih masih rendah. Masing-masing sibuk dengan tugas masing-masing. Hal ini juga dimaksudkan agar peserta mengubah cara kerja mereka. 
Hal lain yang berbeda dari kegiatan siklus I adalah koreksi untuk tugas yang bersifat teori tidak lagi dilakukan oleh peneliti, tetapi dilaksanakan oleh peserta bimbingan melalui koreksi silang. Hal ini dimaksudkan agar timbul perasaan malu terhadap kelompok lain jika skor anggota kelompoknya rendah sehingga diharapkan tercipta kerja sama yang baik, kesungguhan dan cermat dalam mengerjakan tugas (LK)

Berdasarkan rekapitulasi hasil kerja tersebut dapat ditampilkan data sebagai berikut .

Tabel 2. Skor Perolehan Hasil kerja Peserta Melalui LK pada Siklus II

\begin{tabular}{|c|c|c|c|c|c|}
\hline $\begin{array}{l}\text { ASPEK } \\
\text { TUGAS }\end{array}$ & LK & $\begin{array}{l}\text { NOMOR } \\
\text { BUTIR LK }\end{array}$ & $\begin{array}{c}\text { PERSENTASE } \\
\text { KETERCAPAIAN }\end{array}$ & $\begin{array}{l}\text { RATA- } \\
\text { RATA }\end{array}$ & KATAGORI \\
\hline \multirow{13}{*}{ 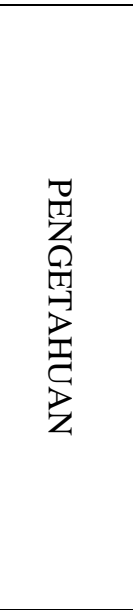 } & \multirow{3}{*}{ LK-12 } & 1 & $89,60 \%$ & \multirow{13}{*}{$95,34 \%$} & \multirow{13}{*}{$\begin{array}{c}\text { BAIK } \\
\text { SEKALI }\end{array}$} \\
\hline & & 2 & $95,80 \%$ & & \\
\hline & & 3 & $94,10 \%$ & & \\
\hline & LK-13 & 1 & $91,67 \%$ & & \\
\hline & \multirow{3}{*}{ LK-14 } & 1 & $99,00 \%$ & & \\
\hline & & 2 & $100 \%$ & & \\
\hline & & 3 & $92,70 \%$ & & \\
\hline & LK-15 & 1 & $99,60 \%$ & & \\
\hline & \multirow[b]{2}{*}{ LK-16 } & 1 & $100 \%$ & & \\
\hline & & 2 & $91,10 \%$ & & \\
\hline & LK-17 & 1 & $100 \%$ & & \\
\hline & LK-21 & 1 & $94,27 \%$ & & \\
\hline & LK-22 & 1 & $91,60 \%$ & & \\
\hline \multirow{3}{*}{$\begin{array}{l}\text { त } \\
\text { 䲶 } \\
\text { 元 }\end{array}$} & LK-18 & 1 & $97,90 \%$ & \multirow{3}{*}{93,73} & \multirow{3}{*}{ Baik Sekali } \\
\hline & LK-8 & 1 & $86,70 \%$ & & \\
\hline & LK-11 & 1 & $96,61 \%$ & & \\
\hline
\end{tabular}

Data di atas menunjukkan bahwa secara umum capaian penguasaan terkait pengetahuan tentang tes/soal bentuk tertulis khususnya bentuk Benar-Salah, Menjodohkan dan Pilihan Ganda termasuk katagori Baik Sekali (95,34\%). Dari 13 butir soal/tugas yang diberikan melalu LK semuanya termasuk katagori Baik Sekali.

Dari aspek praktik, secara umum kemampuan peserta dalam menyusun soal bentuk tertulis khususnya bentuk Benar-Salah, menjodohkan dan pilihan ganda termasuk katagori Baik Sekali (93,73\%). Dilihat dari kemampuan menyusun soal baik bentuk Benar-Salah, menjodohkan maupun pilihan ganda juga termasuk katagori Baik Sekali.

Berdasarkan uraian di atas dapat dikemukakan bahwa kegiatan penyusunan tes bentuk tertulis melalui bimbingan berbasis Lembar Kerja (LK) pada siklus II menunjukkan peningkatan yang signifikan baik dalam hal pengetahuan maupun kemampuan menyusun tes bentuk tertulis. 


\section{Pembahasan}

Sebagaimana telah dikemukakan di atas bahwa hasil kegiatan bimbingan pada siklus I sudah menunjukkan hasil yang cukup baik. Namun demikian juga masih ada yang belum. Setelah dilakukan sedikit perubahan/perbaikan tampak hasilnya ada kemajuan yang cukup signifikan. Hal ini dapat dilihat pada tabel berikut ini.

Tabel 3. Skor Perolehan Hasil Telaah LK pada Siklus I dan II

\begin{tabular}{|c|c|c|l|}
\hline \multirow{2}{*}{ SIKLUS } & ASPEK & $\begin{array}{c}\text { RATA-RATA } \\
\text { SKOR } \\
\text { PEROLEHAN }\end{array}$ & KATAGORI \\
\hline \multirow{2}{*}{ SIKLUS I } & PENGETAHUAN & 84,63 & Baik \\
\cline { 2 - 4 } & PRAKTIK & 68,14 & Cukup \\
\hline \multirow{2}{*}{ SIKLUS II } & PENGETAHUAN & 95,34 & Baik Sekali \\
\cline { 2 - 4 } & PRAKTIK & 93,73 & Baik Sekali \\
\hline
\end{tabular}

Data di atas menunjukkan bahwa pada aspek penguasaan pengetahuan terjadi peningkatan persentase keberhasilan sebesar 10,71\% (dari 84,63\% menjadi 95,34\%). Dari katagori Baik menjadi katagori Baik Sekali. Demikian pula halnya pada aspek praktik dimana telah terjadi peningkatan yang sangat signifikan yaitu sebesar 25,59 (dari 68,14 menjadi 93,73). Sehingga yang tadinya berada pada katagori Cukup meningkat menjadi Baik Sekali.

Pada aspek semangat kerja, berdasarkan hasil pengamatan melalui lembar observasi menunjukkan bahwa peserta bimbingan (guru-guru) bersemangat mengikuti kegiatan bimbingan (penyusunan instrumen penilaian bentuk tes tertulis). Hal ini dapat dilihat dari kehadiran semua peserta ke ruang kegiatan yang tepat waktu, memiliki tanggung jawab yang baik bahkan ada beberapa orang sangat tinggi, kerja sama antar anggota kelompok yang awalnya kurang tapi pada siklus ke dua menunjukkan kerja tim yang baik. Mereka juga tampak senang, antusias meskipun tampak serius. Ini menunjukkan bahwa penerapan model Bimbingan Berbasis Lembar Kerja (LK) juga dapat membuat guru lebih bersemangat dalam menyusun instrumen penilaian bentuk tes tertulis. Hal ini didukung oleh pendapat guru dari hasil angket bahwa semuanya (100\%) menyatakan model bimbingan berbasis lembar kerja (LK) dapat meningkatkan keaktifan peserta.

Dari segi kelebihan model bimbingan berbasis LK dibanding model ceramah atau model bimbingan yang lain (angket nomor 2) berbagai pendapat mereka kemukakan. Ada sejumlah pendapat yang sama yaitu tidak membosankan (10 orang). Ada juga pendapat yang merupakan pengulangan sekaligus penegasan angket nomor 1 yaitu dapat membuat peserta aktif ( 19 orang) yang dikemukakan dengan bahasa/kalimat yang berbeda. Semua guru terlibat ( 8 orang). Terjadi kerja sama/diskusi (13 orang). Lebih mudah memahami (4 orang). Pembelajaran terarah sesuai urutan dan sistematis (3 orng).

Pendapat lain mengenai kelebihan bimbingan berbasis lembar kerja adalah lebih banyak melibatkan peserta dalam pembelajaran, lebih mudah mengingat materi karena harus membaca dan menulis, lebih termotivasi, menambah 
wawasan pengetahuan, memperkaya dan memperluas pembelajaran, tidak membuat mata mengantuk, guru dituntut untuk selalu sip dikoreksi dan presentasi sehingga ada persaingan, paling mudh dilaksanakan, dapat dipelajari dimana saja. Semua pndapat guru tersebut menggambarkan bahwa banyak kelebihan yang diperoleh dengan diterapkannya model bimbingan berbasis lembar kerja.

Dari aspek kemanfaatan dari kegiatan bimbingan ini, peserta juga mengemukakan berbagai pendapat. Ada beberapa pendapat yang maksudnya sama namun menggunakan kalimat yang berbeda yaitu tahu cara membuat soal yang baik dan benar (22 orang). Pendapat mereka yang lainnya adalah bisa membuat soal dengan baik dan benar, dapat ilmu baru yang dulu tidak tahu (6 orang), lebih mengenal maksud dan tujuan penilaian hasil belajar, pembelajaran lebih bermakna, memiliki gambaran yang lebih jelas dan menyeluruh, melakukan kegiatan membaca pemahaman, harus membaca dan meneliti jawaban yang benar, bekerja sama dalam kelompok. Bisa mengecek jawaban melalui koreksi bersama. Berdasarkan pendapat di atas dapat disimpulkan bahwa kegiatan bimbingan ini memberikan manfaat yang banyak bagi guru.

Dari aspek perasaan peserta dalam mengikuti kegiatan bimbingan berbasis lembar kerja diketahui sebanyak 20 orang menyatakan menyenangan dan sebagian peserta menambahkan dengan kata walaupun cukup melelahkan. Pendapat yang lain adalah cukup menarik karena tidak ceramah melulu, sangat bangga karena dari kegiatan bimbingan ini dapat mengetahui penyusunan tes bentuk tertulis, sangat terbantu karena selama ini tes yang dibuat kurang bervariasi, pembelajaran lebih aktif, meningkatkan cara kecakapan berpikir dan terjadi kerja sama, kekeluargaan antar guru dan persaingan yang menguntungkan. Kesimpulan yang dapat kita ambil adalah mereka senang mengikuti kegiatan bimbingan berbasis lembar kerja

\section{PENUTUP}

Berdasarkan hasil penelitian dan pembahasan dapat disimpulkan bahwa penerapan model Bimbingan Berbasis Lembar Kerja (LK) dapat meningkatkan kemampuan guru dalam menyusun instrumen penilaian bentuk tes tertulis di SMP Negeri 7 Banjarmasin.

\section{DAFTAR RUJUKAN}

Depdiknas. (2008). Pengembangan Bahan Ajar dan Media pembelajaran, Jakarta: Direktorat Pembinaan SMP.

Djiwandono, M. Soenardi (1996). Tes bahasa dalam pengajaran. Bandung: Penerbit ITB.

Furqon. (1999). Sistem penilaian kelas untuk meningkatkan mutu kegiatan belajar mengajar. Buletin Pengujian dan Evaluasi Pendidikan, Triwulan/3/VII.69.

Hotibin. Pendidikan orang dewasa. Diakses tanggal 7 September 2015 dari http://kangebink.blogspot.co.id/2013/08/andragogi-pendidikan-orangdewasa.html). 
Meningkatkan Kemampuan Guru dalam Menyusun

Instrumen Penilaian Bentuk Tes Tertulis Melalui Bimbingan Berbasis Lembar Kerja di SMP Negeri 7 Banjarmasin

Https://en.wikipedia.org/wiki/Adult_education. Diakses tanggal 7 September 2015

Https://en.wikipedia.org/wiki/Worksheet). Diakses tanggal 7 September 2015

Peraturan Menteri Pendidikan Nasional Nomor 20 Tahun 2007. Tentang Standar Penilaian, Jakarta: Mendiknas.

Undang-Undang Republik Indonesia Nomor 14 tahun 2005. Tentang Guru Dan Dosen. Bandung: Citra Umbara. 